Agro-Science Journal of Tropical Agriculture, Food, Environment and Extension Volume 20 Number 2 (April 2021) pp. 49 - 56

ISSN 1119-7455

\title{
EFFECTS OF FOUR ORGANIC AMENDMENTS ON SOIL PHYSIOCHEMICAL PROPERTIES AND YIELD OF MAIZE (Zea mays) AND COWPEA (Vigna unguiculata) INTERCROP IN AWKA, SOUTHEASTERN NIGERIA
}

\author{
${ }^{1}$ Onunwa A.O., ${ }^{1 *}$ Nwaiwu C.J., ${ }^{1}$ Nwankwor J.E., ${ }^{1}$ Emeh C.E., ${ }^{1}$ Madueke C.O. and ${ }^{2}$ Igwe C.A. \\ ${ }^{1}$ Department of Soil Science \& Land Resources Management, \\ Nnamdi Azikiwe University, Awka, Anambra State, Nigeria \\ ${ }^{2}$ Department of Soil Science, University of Nigeria, Nsukka, Enugu State, Nigeria \\ *Corresponding author's email: cj.nwaiwu@unizik.edu.ng
}

\begin{abstract}
Effects of four organic amendments on some soil physical and chemical properties were investigated in Awka, Anambra State in southeastern Nigeria. Over the years, use of synthetic materials in crop production has been a common practice globally. The attendant detrimental effects of the chemicals used in the formulation of these synthetics on animal and human health as well as the environment has made researchers to look out for a better agronomic practice that would not only improve productivity but at the same time sustain a healthy environment. Sole maize, sole cowpea and maize-cowpea intercrop (study area conventional practices) were planted using four soil organic amendments viz: cassava peel (CP), poultry

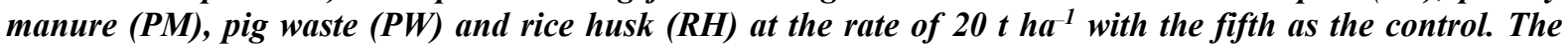
treatments were laid out in a $3 \times 5$ factorial in randomized complete block design and replicated four times. Data on the treatments' effects on the selected soil physical properties (bulk density, total porosity, soil moisture) and chemical properties (soil pH, available phosphorus, cation exchange capacity (CEC), organic carbon, exchangeable bases and exchangeable acidity) were subjected to factorial analysis of variance using GenStat 2006 Edition. Results indicated that for sole maize, the amendments had significant effect on exchangeable $\mathrm{Al}^{3+}$ and $\mathrm{Na}^{+}$; organic carbon, soil $\mathrm{pH}$, available phosphorus and $\mathrm{CEC}$ but had no significant effect on $\mathrm{Ca}^{2+}, \mathrm{H}^{+}, \mathrm{Mg}^{2+}$ and $\mathrm{K}^{+}$as compared to the control. For sole cowpea, compared to the plots with no amendment (control), all the chemical parameters analyzed differed significantly except organic carbon. Whereas, for maize-cowpea intercrop the treatments had no significant effect on $\mathrm{Al}^{3+}, \mathrm{Na}^{+}, \mathrm{K}^{+}$and available phosphorus but differed significantly in exchangeable $\mathrm{H}^{+}, \mathrm{Ca}^{2+}, \mathrm{Mg}^{2+}$, organic carbon, soil pH, and CEC. There was a decrease in bulk density following the amendment. For sole maize, sole cowpea and maizecowpea intercrop; bulk density, total porosity and moisture content of the amended plots were significantly (p $<0.05)$ influenced. Organic amendments also significantly improved the growth and yield of maize and cowpea in both the sole and intercrop systems. Generally, poultry manure resulted in higher plant height, number of leaves and leaf area for maize; vine length, number of branches for cowpea as compared with other amendments. Hence, poultry manure was the most effective organic amendment in improving the soil physical and chemical properties as well as the growth and yield of cowpea and maize.
\end{abstract}

Key words: Growth, maize-cowpea intercrop, soil physical and chemical properties, soil organic amendments

\section{INTRODUCTION}

Organic matter is a critical factor in the management of especially tropical soils (Obalum et al., 2011). It is a good indicator of soil quality as it affects many of the physical, chemical and biological processes that define soil productivity (Bot and Benites, 2005; Obalum et al., 2017). The limitations of agricultural production include inadequate nutrient supply which is controlled mostly by organic matter content, as well as the physical and chemical properties of the soil (Warman, 1981; Chan et al., 2003). Soil fertility maintenance is a major concern in the tropics (Okonkwo et al., 2011). When a soil is cultivated continuously without replacement of the soil nutrient, its productivity gradually decreases due to depletion of organic matter which is believed to be a reservoir of plant nutrients (Ebaid and El-Refaee, 2007; Eneje and Uzoukwu, 2012). Agriculture is a soil-based industry that extracts nutrients from the soil, hence the need for effective and efficient approaches that will slow down nutrient removal as well as enhance returning of nutrients to the soil in order to maintain and increase crop productivity and sustain agriculture in the long run (Gruhn et al., 2000). Soil fertility replenishment should be considered a necessity in the enhancement of agricultural productivity (Sanchez et al., 1997). Reversing soil fertility

Please cite as: Onunwa A.O., Nwaiwu C.J., Nwankwor J.E., Emeh C.E., Madueke C.O. and Igwe C.A. (2021). Effects of four organic amendments on soil physiochemical properties and yield of maize (Zea mays) and cowpea (Vigna unguiculata) intercrop in Awka, Southeastern Nigeria. Agro-Science, 20 (2), 49-56. DOI: https://dx.doi.org/10.4314/as.v20i2.8 
depletion is one of the requirements for increasing per capita agricultural production in Africa (Sanchez and Leakey, 1997) especially in Nigeria. Organic materials added to the soil have the ability to improve soil quality. Soil quality indicators (SQI) include a range of soil physical, chemical and biological characteristics which are connected to key soil ecosystem functions (such as climate and water regulation, nutrient cycling, land structure and stability, and soil microbial and plant biodiversity) and promote soil productivity. Organic waste used as amendment should be able to meet the nutrient requirements of the plants as well as enhance many functions of the soil (Madhumita et al., 2009; Demir and Gulser, 2015).

Due to the increasing cost of chemical fertilizers and the associated depletion of soil micronutrients, environmental and health hazards of these chemicals as well as the usual premium prices for crops grown with manure globally, the use of manures in farming is often advocated (Ramesh et al., 2005). Application of manures from livestock is an important means of recycling nutrients in the soil (Petersen et al., 2007; Sommer et al., 2013). Also, manures from livestock rearing support crop farming and vice versa, making them easier to obtain compared to mineral fertilizers (Kolavalli and Adam, 2011). Some less used agrowastes such as rice husk and pig waste have shown great potential as manures (Adubasim et al., 2018; Baiyeri et al., 2020; Ugwu et al., 2021).

Crews and Peoples (2004) stated that although chemical fertilizers release their nutrients faster into the soil for plant uptake, their deleterious effects (water way pollution, chemical burn to crops, increased air pollution, acidification of the soil and mineral depletion in the soil) have brought a lot of concern on sustainability of production. According to Savci (2012), the detrimental effects of chemical fertilizers on the soil are not immediately evident because soils have strong buffering capacity but the toxic substances (lead, mercury, dioxins and polychlorinated biphenyls (PCBs) that accumulate within the crops could cause harm to humans and animals who consume them.

Soil fertility depletion in small-holder farms is the fundamental biophysical cause for declining food production in sub-Saharan Africa (Nabhan, 1997) especially in Nigeria. If the nutrient removal rate of crops is not checked by practices that maintain the fertility of the soil, the soil nutrient will be impoverished or depleted and productivity will decline (Logah, 2009).

Cereal-legume intercropping plays an important role in subsistence food production in both developed and developing countries (Tsubo et al., 2005). Yields of intercrop are often higher than in sole cropping systems (Lithourgidis et al., 2006). Intercropping of cereal and legume crops help maintain and improve soil fertility because legumes fix atmospheric nitrogen $(\mathrm{N})$, which may be utilized by the host plant, or may be excreted from the nodules into the soil and be used by other plants growing nearby (Andrew and Jones, 1978). Hence, organic cereal-legume intercropping system will produce higher yields to the rural farmers in Nigeria as well as improve the Gross Domestic Product (GDP) and nation's economy than inorganic sole cropping system.

There is paucity of information on the effects of organic amendments on the physical and chemical properties of soils in Anambra State especially in Awka, besides, some of these organic amendments (cassava peels and rice husk) are often burnt or wasted, hence this study is designed to determine the effects of four organic amendments on the physicochemical properties of the soil using sole and intercropped maize and cowpea as test crops in Awka, southeastern Nigeria.

\section{MATERIALS AND METHODS \\ Site Description}

The field study was conducted at the Research Farm of the Department of Soil Science \& Land Resources Management, Faculty of Agriculture, Nnamdi Azikiwe University Awka, southeastern Nigeria. The textural class of the experimental site is sandy loam with the parent material as Imo clay shale. It is a flat land that has been under fallow for about 5 years. Awka falls within the rainforest zone of the southeastern Nigeria and is located on latitude $6^{\circ} 14^{\prime} \mathrm{N}$ and longitude $7^{\circ} 07^{\prime} \mathrm{E}$, with an elevation of $105 \mathrm{~m}$ asl. The experimental site is characterized by humid tropical wet and dry seasons with annual rain fall of $1650-2000 \mathrm{~mm}$, an annual temperature range of $27-32^{\circ} \mathrm{C}$ and relative humidity of $75-85 \%$. The vegetation is grassland with some big trees and a few shrubs (Ezenwaji et al., 2014).

\section{Soil Sampling and Preparation}

Both disturbed and undisturbed soil samples were collected at pre-treatment and post-harvest, using soil auger for the disturbed and core sampler for the undisturbed at $0-15 \mathrm{~cm}$ depth. The undisturbed core samples were soaked to saturation before oven drying to determine bulk density and other soil physical properties; the disturbed samples were prepared (air dried and sieved with $2 \mathrm{~mm}$ sieve) before analysis. The pre-treatment samples were collected randomly, composited and prepared before the characterization/analysis. These analyses were carried out at the Soil Science and Land Resources Management laboratory, Faculty of Agriculture, Nnamdi Azikiwe University, Awka.

\section{Amendment Sampling and Processing}

Pig waste and poultry manure were collected from a local animal farm in Awka. Cassava peel was collected from local garri/cassava flour processors at Ifite, Awka. Rice husk was sourced from a rice mill in Omor, Ayamelum Local Government Area in Anambra State. The amendments were bagged 
and allowed to cure for two weeks before use. Samples of the amendments were taken to the laboratory to determine their chemical properties (organic carbon, available phosphorus and exchangeable bases $-\mathrm{Ca}^{2+}, \mathrm{Mg}^{2+}$ and $\mathrm{K}^{+}$). Maize (Oba Super II) of the premier maize hybrid seed was collected from Agricultural Development Programme (ADP) office Amawbia, while Cowpea (local variety, Akidi-ani) was sourced locally from contact farmers Nsukka, Enugu State.

\section{Characterization of Baseline Properties of Soil}

The pre-treatment core soil samples randomly collected from the field at a $0-15 \mathrm{~cm}$ depth were used to determine soil bulk density by core method (Blake and Hartge, 1986), as well as total porosity from the bulk density and gravimetric moisture content using the method described by Jalota et al. (1998). The disturbed soil samples collected at the same depth were prepared, composited and analyzed for particle size distribution using hydrometer method as described by Gee and Bauder (1986); as well as some soil chemical properties including soil $\mathrm{pH}$ determined using $\mathrm{pH}$ meter by McLean (1982), organic carbon using modified Walkley-Black procedure by Nelson and Sommers (1982), available phosphorous using calorimetric method by Bray and Kurtz (1945), and the exchangeable bases $-\mathrm{K}^{+}, \mathrm{Ca}^{2+}, \mathrm{Mg}^{2+}$ and $\mathrm{Na}^{+}$. These basic cations were extracted with $1.0 \mathrm{~N} \mathrm{NH}_{4} \mathrm{OAc}$ after which $\mathrm{K}^{+}$was determined on flame photometer by Richards (1954), and $\mathrm{Ca}^{2+}$ and $\mathrm{Mg}^{2+}$ by EDTA titration method. Exchangeable acidity $\left(\mathrm{Al}^{3+}\right.$ and $\left.\mathrm{H}^{+}\right)$ was determined by titration with $\mathrm{NaOH}$ solution.

\section{Field Method}

A land area of $675 \mathrm{~m}^{2}$ was cleared manually and ploughed mechanically, mapped out and pegged according to the treatment specifications. The experimental design used was $3 \times 5$ factorial in Randomized Complete Block Design (RCBD). The land was divided into 3 main plots, one for each of the three cropping systems: sole maize, sole cowpea, and maize-cowpea intercrop. Each main plot (measuring $15 \mathrm{~m}$ long $\times 15 \mathrm{~m}$ wide $=225 \mathrm{~m}^{2}$ ) was divided into 5 split plots (measuring $3 \mathrm{~m}$ long $\times 2.5 \mathrm{~m}$ wide $=7.5 \mathrm{~m}^{2}$ ) for the five treatments (poultry manure, pig waste, cassava peel, rice husk and the unamended (control)). Each treatment was replicated four times. Each of the cured organic amendments was applied at the rate of $20 \mathrm{t} \mathrm{ha}^{-1}$ by broadcasting and incorporated into the soil. This was done two weeks before planting.

Maize was sown 3 seeds per hole at a spacing of $60 \mathrm{~cm} \times 40 \mathrm{~cm}$ and later thinned down to 1 plant per stand and cowpea was sown 3 seeds per hole at a spacing of $80 \mathrm{~cm} \times 60 \mathrm{~cm}$ and later thinned down to 1 plant per stand one week after emergence; giving a plant population of 41,667 plants $\mathrm{ha}^{-1}$ for maize and 20,833 plants ha ${ }^{-1}$ for cowpea.

\section{Agronomic Data Collection}

Data were collected at 4 and 8 weeks after planting (WAP) from three maize plants and three cowpea plants used as experimental units. Plant height for maize and vine length for cowpea were measured using a tape rule. Number of leaves for maize and number of branches for cowpea were counted by observation; leave area for maize was calculated. The yield parameters (weight of maize cob and weight of cowpea pods) were taken using a sensitive weighing balance, while the number of maize cob was counted by observation.

\section{Post-Harvest Soil Sampling and Analyses}

Core and auger soil samples were collected from the experimental site at $0-15 \mathrm{~cm}$ depth according to the various treatments after harvest, prepared and taken to the laboratory for analysis in order to determine the effects of the organic amendments on the physical and chemical properties of the soil.

The core soil samples were used to determine bulk density, total porosity and moisture content, while the auger collected samples were used to determine some chemical properties of the soil (soil $\mathrm{pH}$, organic carbon, available phosphorus, exchangeable bases and acidity), using standard analytical procedures as outlined above. These analyses were carried out at the laboratory of Soil Science \& Land Resources Management, Faculty of Agriculture, Nnamdi Azikiwe University, Awka.

\section{Data Analysis}

Soil and crop data were subjected to factorial analysis of variance (ANOVA) following the routine procedure for RCBD experiments using GenStat 2006 edition (GenStat, 2006). Mean separation was done using Fisher's least significant difference (F-LSD) at 5\% probability level.

\section{RESULTS AND DISCUSSION}

Table 1 shows the results of initial soil analysis carried out to assess the soil fertility status before the study. Soil organic carbon was $1.23 \%$. Available phosphorous was $25.69 \mathrm{ppm}$ while soil $\mathrm{Ca}^{2+}$ and $\mathrm{Mg}^{2+}$ were 5.44 and $4.53 \mathrm{meq} 100-\mathrm{g}^{-1}$ soil, respectively. The soil was slightly acidic with a $\mathrm{pH}$ of 6.2 . The soil texture was sandy loam.

Table 2 shows the results of the proximate analysis on the four amendments used in the study. Poultry manure (PM) ranked highest in all the parameters analyzed except for calcium which was highest in pig waste. Rice husk (RH) showed the lowest values of all the parameters, except for organic carbon which was lowest in cassava peels. These results informed the decision to use $20 \mathrm{t} \mathrm{ha}^{-1}$ for PM instead of the conventional $10 \mathrm{tha}^{-1}$.

Tables 3, 4 and 5 show the effects of the different organic amendments on soil physical properties in sole maize, sole cowpea and maizecowpea intercrop respectively. 
Table 1: Baseline data on the physiochemical properties of the soil

\begin{tabular}{ll}
\hline Soil property & Values \\
\hline$(\%)$ sand & 72.60 \\
$(\%)$ clay & 3.94 \\
$(\%)$ silt & 23.46 \\
Soil texture & Sandy loam \\
$\mathrm{pH}$ & 6.20 \\
Bulk density $\left(\mathrm{Mg} \mathrm{m}^{-3}\right)$ & 2.61 \\
Moisture content $\left(\mathrm{m}^{3} \mathrm{~m}^{-3}\right)$ & 10.49 \\
Total porosity $\left(\mathrm{m}^{3} \mathrm{~m}^{-3}\right)$ & 25.42 \\
Organic carbon $(\%)$ & 1.23 \\
Available phosphorus (ppm) & 25.69 \\
Exchangeable $\mathrm{K}\left(\mathrm{meq} 100 \mathrm{~g}^{-1}\right.$ of soil) & 16.89 \\
Exchangeable $\mathrm{Ca}\left(\mathrm{meq} 100 \mathrm{~g} \mathrm{~g}^{-1}\right.$ of soil) & 5.44 \\
Exchangeable $\mathrm{Mg}\left(\mathrm{meq} 100 \mathrm{~g}^{-1}\right.$ of soil) & 4.53 \\
Exchangeable $\mathrm{Na}\left(\mathrm{meq} 100 \mathrm{~g} \mathrm{~g}^{-1}\right.$ of soil) & 19.40 \\
Exchangeable $\mathrm{H}^{+}$ & 0.90 \\
Exchangeable $\mathrm{Al}^{3+}$ & 0.80 \\
\hline
\end{tabular}

Table 2: Chemical properties of the amendments used

\begin{tabular}{lccccc}
\hline \multirow{2}{*}{ Amendment } & \multirow{2}{*}{$\begin{array}{c}\text { Org. C } \\
\text { (\%) }\end{array}$} & \multirow{2}{*}{$\begin{array}{c}\text { Ava. P } \\
\text { (ppm) }\end{array}$} & & \multicolumn{3}{c}{ Exch. bases } \\
\cline { 4 - 6 } \cline { 4 - 5 } & & \multicolumn{2}{c}{ (meq } & Ca $\mathrm{g}^{-1}$ of soil $)$ \\
\hline $\mathrm{CP}$ & 23.13 & 2.80 & 18.0 & 8.95 & 1.92 \\
$\mathrm{PM}$ & 32.26 & 3.30 & 25.0 & 9.25 & 3.85 \\
$\mathrm{PW}$ & 27.13 & 2.16 & 22.0 & 9.95 & 1.95 \\
$\mathrm{RH}$ & 29.51 & 2.05 & 12.0 & 7.25 & 0.89 \\
\hline $\mathrm{CP}$ - cassava peel; PM - poultry manure; PW - pig waste; \\
RH - rice husk; Org. C - organic carbon; Ava. P - available \\
phosphorous; Exch. bases - exchangeable bases
\end{tabular}

For sole maize (Table 3), bulk density had a statistically significant variation among the treatments used. The highest was in the control plot and least in the RH treated plots. The low bulk densities of the treated plots compared to the baseline data (2.61) suggests that the application of organic amendments improved the organic matter content of the soil as well as the total porosity (30.24-42.28) as against the baseline data (25.42). The decrease in the unamended plot compared to the baseline data could be attributed to overflow effect of the amendments applied on the other plots. The order of differences in bulk density was NA $>$ PW $>$ CP $>$ PM $>$ RH. Total porosity increased significantly and this study showed that rice husk had the highest value while the unamended (control) recorded the lowest. The decrease in bulk density could be attributed to the low density of manure and its tendency to increase pore size and volume at high doses (20 and $80 \mathrm{mg} \mathrm{ha} \mathrm{ha}^{-1}$ ) (Gallardo-Laraa and Nogales, 1987). The soil moisture content was highest on plots amended with pig waste followed by poultry manure, rice husk, cassava peel and the control.

For sole cowpea (Table 4), the bulk density of the soil was significantly $(p<0.05)$ higher in the plots with no amendment than the treated plots. Rice husk treated plots showed the lowest bulk density. The result agrees with the work done by Nnoke (2005) which showed that organic amendment enhanced the total porosity of the soil by increasing the soil pore spaces which invariably reduced soil bulk density.
For maize-cowpea intercrop (Table 5), organic amendments significantly affected soil moisture content. It was observed that moisture content was greater in plots treated with PM than RH, PW, and $\mathrm{CP}$ which were greater than the control plot. Soil organic amendments also affected bulk density in the following order NA $>\mathrm{CP}>\mathrm{PW}>\mathrm{PM}>\mathrm{RH}$. This is similar to Ewulo et al. (2008) observation that organic manure, and in particular, poultry manure, reduced soil bulk density and enhanced its moisture content. Also Anikwe (2000) reported that rice husk decreased soil dry bulk density. Mbagwu (1992) showed that the decrease in bulk density obtained with rice husk and poultry manure treated soils were directly related to improvement in the organic matter content which plays a significant role in reducing the degree of compaction of the soil. Babalola et al. (2015) equally asserted that organic fertilizer improves soil bulk density, structure, total porosity, cation exchange capacity, therefore, the use of organic manure is important for sustainable land use management.

Table 3: Effects of organic amendment on soil physical properties for sole maize

\begin{tabular}{lccc}
\hline Treatment & $\begin{array}{c}\mathrm{BD} \\
\left(\mathrm{Mg} \mathrm{m}^{-3}\right)\end{array}$ & $\begin{array}{c}\mathrm{MC} \\
\left(\mathrm{m}^{3} \mathrm{~m}^{-3}\right)\end{array}$ & $\begin{array}{c}\mathrm{TP} \\
\left(\mathrm{m}^{3} \mathrm{~m}^{-3}\right)\end{array}$ \\
\hline $\mathrm{CP}$ & 1.61 & 13.50 & 35.06 \\
$\mathrm{PM}$ & 1.58 & 14.55 & 30.24 \\
$\mathrm{PW}$ & 1.72 & 14.63 & 40.39 \\
$\mathrm{RH}$ & 1.45 & 14.18 & 42.28 \\
$\mathrm{NA}$ & 1.80 & 13.43 & 32.07 \\
LSD & 0.02 & 0.03 & 0.04 \\
\hline CP - cassava peel; PM - poultry manure; RH - rice husk; \\
PW - pig waste; NA - no amendment; BD - bulk density; \\
MC - moisture content; TP - total porosity
\end{tabular}

Table 4: Effects of organic amendment on soil physical properties for sole cowpea

\begin{tabular}{lccc}
\hline Treatment & $\begin{array}{c}\mathrm{BD} \\
\left(\mathrm{Mg} \mathrm{m}^{-3}\right)\end{array}$ & $\begin{array}{c}\mathrm{MC} \\
\left(\mathrm{m}^{3} \mathrm{~m}^{-3}\right)\end{array}$ & $\begin{array}{c}\mathrm{TP} \\
\left(\mathrm{m}^{3} \mathrm{~m}^{-3}\right)\end{array}$ \\
\hline CP & 1.61 & 13.50 & 35.06 \\
PM & 1.58 & 14.55 & 39.24 \\
PW & 1.71 & 14.63 & 40.39 \\
RH & 1.44 & 14.18 & 42.25 \\
NA & 1.79 & 13.43 & 32.07 \\
LSD $_{0.05}$ & 0.23 & 0.03 & 0.04 \\
\hline
\end{tabular}

CP - cassava peel; PM - poultry manure; $\mathrm{RH}$ - rice husk; PW - pig waste; NA - no amendment; BD - bulk density; $\mathrm{MC}$ - moisture content; TP - total porosity

Table 5: Effects of organic amendment on soil physical properties for maize-cowpea

\begin{tabular}{lccc}
\hline Treatment & $\begin{array}{c}\mathrm{BD} \\
\left(\mathrm{Mg} \mathrm{m}^{-3}\right)\end{array}$ & $\begin{array}{c}\mathrm{MC} \\
\left(\mathrm{m}^{3} \mathrm{~m}^{-3}\right)\end{array}$ & $\begin{array}{c}\mathrm{TP} \\
\left(\mathrm{m}^{3} \mathrm{~m}^{-3}\right)\end{array}$ \\
\hline $\mathrm{CP}$ & 1.57 & 12.26 & 31.80 \\
$\mathrm{PM}$ & 1.53 & 14.24 & 41.22 \\
$\mathrm{PW}$ & 1.55 & 12.50 & 39.20 \\
$\mathrm{RH}$ & 1.35 & 12.64 & 42.25 \\
$\mathrm{NA}$ & 1.80 & 10.72 & 33.08 \\
LSD & 0.05 & 0.30 & 0.05 \\
\hline CP - cassava peel; PM - poultry manure; RH - rice husk; \\
PW - pig waste; NA - no amendment; BD - bulk density; \\
MC - moisture content; TP - total porosity
\end{tabular}


Tables 6,7 and 8 show the effects of organic amendments on soil chemical properties for sole maize, sole cowpea and maize-cowpea intercrop, respectively. For sole maize (Table 6), the amended plots had higher cation exchange capacity (CEC), aluminum, organic carbon and available phosphorous than the control. Although $\mathrm{H}^{+}, \mathrm{Ca}^{2+}$, $\mathrm{Mg}^{2+}$ and $\mathrm{K}^{+}$were not significantly different; poultry manure was the most effective having the highest value except for $\mathrm{H}^{+}$. This result is expected, from the characterization of the amendments, poultry manure ranked highest in all the parameters tested compared to the other amendments used (Table 2). This justifies the preference of poultry manure to other organic amendments in conservation agriculture as studied by Mengel and Kirkby (2001). Soil pH was significantly different among the treatments. Plots treated with poultry manure had the highest $\mathrm{pH}$ while the plot treated with cassava peel had the least, thus indicating that $\mathrm{CP}$ could lead to soil acidification evidenced by the high exchangeable acidity values (Table 6 ).

The low $\mathrm{pH}$ recorded by cassava peels is generally due to the presence of toxic cyanogenic glucosides in unfermented roots, peels and leaves of cassava as reported by Cereda and Mattos (1996). For organic carbon the treatments were statistically different, the control recorded the least value while PM had the highest value. This result confirmed that in addition to enhancing soil physical properties, organic amendments also improves soil nutrient/chemical properties (Nnabude and Mbagwu, 1999).

For sole cowpea (Table 7), the highest organic carbon was observed in the PM amended soil while the lowest occurred in the unamended soil. Poultry manure showed higher CEC when compared to other amendments while CP had the least value. Aluminum was highest in the soil treated with cassava peels and lowest in the soil treated with poultry manure. $\mathrm{H}^{+}$was highest in soil treated with $\mathrm{CP}$ and lowest in soil treated with PM. The exchangeable $\mathrm{Al}^{3+}$ was significantly different among the treated soils while $\mathrm{H}^{+}$was not.

There were significant differences in the exchangeable bases $\left(\mathrm{Ca}^{2+}, \mathrm{Mg}^{2+}, \mathrm{Na}^{+}, \mathrm{K}^{+}\right)$among the treated soils, with poultry manure proving to be more effective than the other treatments. The $\mathrm{Ca}^{2+}$, $\mathrm{Mg}^{2+}$ and $\mathrm{K}^{+}$were highest in the soil treated with $\mathrm{PM}$ and least in the control. $\mathrm{Na}^{+}$showed the highest value in the control and the least value in PM. This result may further justify the higher performance of soil amended with PM under sole cowpea cropping system as evidenced in the number of branches, vine length and yield (Table 10).

The result of the study revealed that there was significantly higher phosphorous in the treated soil than in plots with no amendments indicating that the applied amendment actually improved the soil phosphorus. The results show that soil $\mathrm{pH}$ was highest in the soil treated with poultry manure and lowest in soil treated with cassava peels. There were significant differences in the $\mathrm{pH}$ of the soil as influenced by the treatments.

For maize-cowpea intercrop (Table 8), the soil $\mathrm{pH}$ in the amended plots (with PM, PW and $\mathrm{RH}$ ) which were statistically the same with the control differed significantly with the $\mathrm{pH}$ of soil amended with $\mathrm{CP}$. The highest soil $\mathrm{pH}$ was observed in the plot amended with PM while the least was observed in the plot amended with cassava peels. The $\mathrm{pH}$ value was in the order $\mathrm{PM}>\mathrm{PW}=\mathrm{RH}=$ NA $>$ CP. Soil exchangeable bases, calcium $(\mathrm{Ca})$ and magnesium $(\mathrm{Mg})$ also changed as a result of the different organic amendments added to the soil compared to the baseline data. $\mathrm{Ca}$ and $\mathrm{Mg}$ differed significantly: they were highest in plots amended with PM while the least values were observed in the control. Meanwhile, $\mathrm{K}$ and $\mathrm{Na}$ showed no significant difference between the amended plots and the control plots. CEC of the amended plots differed significantly from that of the plot with no amendment. The highest CEC was observed in the plot amended with PM while the least was observed in the control. Percentage organic carbon differed significantly among the treatments in this order: $\mathrm{PM}>\mathrm{RH}>\mathrm{PW}>\mathrm{CP}>\mathrm{NA}$.

Tables 9, 10 and 11 show the effects of the different organic amendments on the growth and yield of sole maize, sole cowpea and maize-cowpea intercrop, respectively. For sole maize (Table 9), the results showed that at 4 and 8 WAP all the growth parameters (plant height, leaf area, number of leaves) were higher in the treated soil than in the soil with no amendment except for cassava peel. The decrease in growth recorded in the cassava peel treated plot could be attributed to hydrogen cyanide content in cassava peel which has been proved to contribute to soil acidity (Desse and Taye, 2001). However, poultry manure gave the highest yield parameter $(p<0.05)$ compared to the other amendments. This could be attributed to the fact that PM releases the nutrients more readily to the soil than the other amendments and as a matter of fact, has better improvement on the soil properties which directly improves the soil productivity. The effect of the soil amendments on the final yield was significant at $p<0.05$ as the yield of the other amendments increased relative to the control except for cassava peels. The results show that poultry manure performed better than the other soil amendments used.

For sole cowpea, the results revealed that, at both 4 and 8 WAP, PM gave the highest number of branches (6.12 and 14.38 , respectively) and the highest vine length $(75.8$ and $351.6 \mathrm{~cm}$, respectively) (Table 10). The yield of cowpea pods was highest in the poultry manure-amended plot (3.93 $\mathrm{t} \mathrm{ha}^{-1}$ ) and lowest in the plot with no amendment (1.61 tha $\mathrm{th}^{-1}$. 
Soil Physiochemical and Maize-Cowpea Responses to Organic Amendments in Southeastern Nigeria 54

Table 6: Effects of organic amendments on soil chemical properties for sole maize

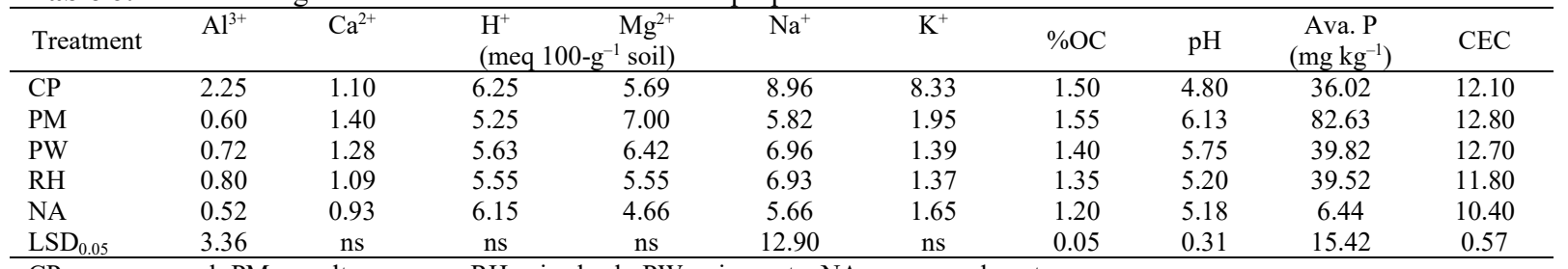

CP - cassava peel; PM - poultry manure; $\mathrm{RH}$ - rice husk; PW - pig waste; NA - no amendment;

OC - organic carbon; Ava. P - available phosphorous; CEC - cation exchange capacity

Table 7: Effects of organic amendments on soil chemical properties for sole cowpea

\begin{tabular}{|c|c|c|c|c|c|c|c|c|c|c|}
\hline \multirow{2}{*}{ Treatment } & $\mathrm{Al}^{3+}$ & $\mathrm{Ca}^{2+}$ & $\mathrm{H}^{+}$ & $\mathrm{Mg}^{2+}$ & $\mathrm{Na}^{+}$ & $\mathrm{K}^{+}$ & \multirow{2}{*}{$\% \mathrm{OC}$} & \multirow{2}{*}{$\mathrm{pH}$} & \multirow{2}{*}{$\begin{array}{c}\text { Ava. P } \\
\left(\mathrm{mg} \mathrm{kg}^{-1}\right)\end{array}$} & \multirow{2}{*}{ CEC } \\
\hline & \multicolumn{6}{|c|}{ (meq 100-g- ${ }^{-1}$ soil) } & & & & \\
\hline $\mathrm{CP}$ & 3.75 & 1.70 & 9.25 & 8.75 & 4.03 & 1.26 & 1.52 & 5.13 & 30.81 & 10.50 \\
\hline PM & 1.55 & 2.45 & 3.38 & 12.25 & 3.54 & 1.66 & 1.56 & 6.33 & 52.63 & 15.62 \\
\hline PW & 2.05 & 1.84 & 8.52 & 9.02 & 3.84 & 1.15 & 1.51 & 5.38 & 32.24 & 12.60 \\
\hline RH & 2.52 & 1.49 & 3.62 & 6.75 & 3.93 & 1.21 & 1.39 & 6.10 & 27.24 & 10.82 \\
\hline NA & 2.28 & 1.36 & 6.68 & 6.68 & 5.96 & 6.45 & 1.38 & 5.23 & 26.23 & 13.23 \\
\hline $\mathrm{LSD}_{0.05}$ & 3.45 & 5.04 & 2.90 & 2.90 & 1.41 & 1.50 & ns & 0.49 & 9.93 & 0.53 \\
\hline
\end{tabular}

CP - cassava peel; PM - poultry manure; RH - rice husk; PW - pig waste; NA - no amendment;

OC - organic carbon; Ava. P - available phosphorous; CEC - cation exchange capacity

Table 8: Effects of organic amendments on soil chemical properties for Maize-cowpea intercrop

\begin{tabular}{|c|c|c|c|c|c|c|c|c|c|c|}
\hline \multirow{2}{*}{ Treatment } & $\mathrm{Al}^{3+}$ & $\mathrm{Ca}^{2+}$ & $\mathrm{H}^{+}$ & $\mathrm{Mg}^{2+}$ & $\mathrm{Na}^{+}$ & $\mathrm{K}^{+}$ & \multirow{2}{*}{$\% \mathrm{OC}$} & \multirow{2}{*}{$\mathrm{pH}$} & \multirow{2}{*}{$\begin{array}{c}\text { Ava. P } \\
\left(\mathrm{mg} \mathrm{kg}^{-1}\right)\end{array}$} & \multirow{2}{*}{ CEC } \\
\hline & \multicolumn{6}{|c|}{ (meq 100-g-1 soil) } & & & & \\
\hline $\mathrm{CP}$ & 1.10 & 1.01 & 1.10 & 0.94 & 1.11 & 4.63 & 1.69 & 5.2 & 57.10 & 11.80 \\
\hline PM & 1.00 & 1.24 & 1.00 & 1.15 & 0.61 & 4.82 & 2.82 & 6.3 & 68.40 & 15.50 \\
\hline PW & 1.00 & 1.13 & 1.00 & 1.04 & 0.93 & 5.50 & 2.22 & 5.8 & 50.70 & 14.82 \\
\hline RH & 1.00 & 1.02 & 1.00 & 1.00 & 0.97 & 5.06 & 2.26 & 5.8 & 48.00 & 12.55 \\
\hline NA & 1.00 & 1.00 & 1.00 & 0.87 & 1.46 & 3.92 & 1.33 & 5.8 & 24.00 & 10.65 \\
\hline $\operatorname{LSD}_{0.05}$ & $\mathrm{~ns}$ & 0.21 & 0.01 & 0.18 & ns & ns & 1.49 & 0.31 & ns & 0.45 \\
\hline
\end{tabular}

$\mathrm{CP}$ - cassava peel; PM - poultry manure; RH - rice husk; PW - pig waste; NA - no amendment;

OC - organic carbon; Ava. P - available phosphorous; CEC - cation exchange capacity

Table 9: Effects of four different soil organic amendments on the growth parameters and yield of sole maize at 4 and 8 WAP

\begin{tabular}{|c|c|c|c|c|c|c|c|}
\hline \multirow[b]{2}{*}{ Treatment } & \multicolumn{3}{|c|}{4 WAP } & \multicolumn{3}{|c|}{8 WAP } & \multirow[b]{2}{*}{$\begin{array}{c}\text { Yield } \\
\left(\mathrm{t} \mathrm{ha}^{-1}\right)\end{array}$} \\
\hline & $\begin{array}{c}\text { Leaf Area } \\
\left(\mathrm{cm}^{2}\right)\end{array}$ & $\begin{array}{l}\text { No of } \\
\text { leaves }\end{array}$ & $\begin{array}{c}\text { Plant height } \\
(\mathrm{cm})\end{array}$ & $\begin{array}{c}\text { Leaf Area } \\
\left(\mathrm{cm}^{2}\right)\end{array}$ & $\begin{array}{l}\text { No of } \\
\text { leaves }\end{array}$ & $\begin{array}{l}\text { Plant height } \\
(\mathrm{cm})\end{array}$ & \\
\hline $\mathrm{CP}$ & 121.13 & 5.41 & 53.8 & 450.18 & 10.25 & 170.7 & 0.009 \\
\hline PM & 564.70 & 11.88 & 122.5 & 725.48 & 14.06 & 256.8 & 0.015 \\
\hline PW & 355.45 & 7.09 & 71.0 & 495.95 & 11.69 & 177.2 & 0.010 \\
\hline RH & 329.68 & 8.38 & 81.9 & 482.83 & 12.12 & 184.1 & 0.010 \\
\hline NA & 197.21 & 6.78 & 69.7 & 463.15 & 10.56 & 170.9 & 0.008 \\
\hline $\mathrm{LSD}_{0.05}$ & 11.96 & 0.99 & 20.55 & 3.20 & 0.65 & 15.25 & 1.42 \\
\hline
\end{tabular}

CP - cassava peel; PM - poultry manure; RH - rice husk; PW - pig waste; NA - no amendment

Table 10: Effects of four different soil organic amendments on the growth parameters and yield of sole cowpea at 4 and 8 WAP

\begin{tabular}{|c|c|c|c|c|c|c|c|}
\hline \multirow[b]{2}{*}{ Treatment } & \multicolumn{3}{|c|}{ 4WAP } & \multicolumn{3}{|c|}{$8 \mathrm{WAP}$} & \multirow[b]{2}{*}{$\begin{array}{l}\text { Yield } \\
\left(\mathrm{t} \mathrm{ha}^{-1}\right)\end{array}$} \\
\hline & $\begin{array}{c}\text { No. of } \\
\text { branches }\end{array}$ & $\begin{array}{l}\text { Vine length } \\
(\mathrm{cm})\end{array}$ & $\begin{array}{l}\text { No. of } \\
\text { leaves }\end{array}$ & $\begin{array}{c}\text { No. of } \\
\text { branches }\end{array}$ & $\begin{array}{l}\text { Vine length } \\
(\mathrm{cm})\end{array}$ & $\begin{array}{l}\text { No. of } \\
\text { leaves }\end{array}$ & \\
\hline $\mathrm{CP}$ & 4.67 & 42.1 & 38.8 & 7.58 & 259.2 & 209.3 & 3.26 \\
\hline PM & 6.12 & 75.8 & 69.8 & 14.38 & 351.6 & 276.6 & 3.93 \\
\hline PW & 4.58 & 57.9 & 49.9 & 9.08 & 201.9 & 185.4 & 1.81 \\
\hline RH & 6.13 & 84.8 & 74.9 & 11.67 & 329.4 & 264.8 & 1.96 \\
\hline NA & 4.58 & 45.8 & 48.1 & 8.25 & 199.3 & 138.2 & 1.61 \\
\hline $\mathrm{LSD}_{0.05}$ & 1.19 & 20.5 & 23.7 & 2.89 & 64.5 & 49.34 & 1.46 \\
\hline
\end{tabular}

CP - cassava peel; PM - poultry manure; RH - rice husk; PW - pig waste; NA - no amendment

Table 11a: Effects of four different soil organic amendments on the growth of maize and cowpea under intercrop at 4 and 8 WAP

\begin{tabular}{|c|c|c|c|c|c|c|c|c|c|c|c|c|}
\hline \multirow[b]{3}{*}{ Treatment } & \multicolumn{6}{|c|}{ Maize } & \multicolumn{6}{|c|}{ Cowpea } \\
\hline & \multicolumn{3}{|c|}{ 4WAP } & \multicolumn{3}{|c|}{ 8WAP } & \multicolumn{3}{|c|}{ 4WAP } & \multicolumn{3}{|c|}{ 8WAP } \\
\hline & $\begin{array}{l}\text { Leaf } \\
\text { area } \\
\left(\mathrm{cm}^{2}\right)\end{array}$ & $\begin{array}{l}\text { No. of } \\
\text { leaves }\end{array}$ & $\begin{array}{l}\text { Plant } \\
\text { height } \\
(\mathrm{cm})\end{array}$ & $\begin{array}{l}\text { Leaf } \\
\text { area } \\
\left(\mathrm{cm}^{2}\right)\end{array}$ & $\begin{array}{l}\text { No. of } \\
\text { leaves }\end{array}$ & $\begin{array}{l}\text { Plant } \\
\text { height } \\
(\mathrm{cm})\end{array}$ & $\begin{array}{l}\text { No. of } \\
\text { branches }\end{array}$ & $\begin{array}{l}\text { Vine } \\
\text { length } \\
(\mathrm{cm})\end{array}$ & $\begin{array}{l}\text { No. of } \\
\text { leaves }\end{array}$ & $\begin{array}{l}\text { No. of } \\
\text { branches }\end{array}$ & $\begin{array}{l}\text { Vine } \\
\text { length } \\
(\mathrm{cm})\end{array}$ & $\begin{array}{l}\text { No. of } \\
\text { leaves }\end{array}$ \\
\hline $\mathrm{CP}$ & 238 & 9.00 & 88.1 & 495 & 13.33 & 153.2 & 5.33 & 64.1 & 25.8 & 11.08 & 293.0 & 115.2 \\
\hline PM & 468 & 10.58 & 109.5 & 625 & 14.25 & 213.8 & 5.75 & 87.2 & 33.9 & 12.58 & 346.0 & 151.5 \\
\hline PW & 408 & 9.00 & 98.8 & 568 & 13.50 & 206.9 & 4.30 & 65.2 & 28.9 & 9.83 & 295.7 & 125.9 \\
\hline $\mathrm{RH}$ & 391 & 9.58 & 104.8 & 522 & 14.00 & 209.4 & 5.50 & 74.7 & 28.3 & 12.17 & 323.9 & 150.8 \\
\hline NA & 121 & 7.42 & 76.8 & 465 & 12.17 & 137.4 & 4.50 & 48.6 & 17.8 & 10.08 & 256.5 & 96.7 \\
\hline $\mathrm{LSD}_{0.05}$ & ns & 1.76 & 20.8 & ns & ns & 48.93 & ns & 18.37 & ns & ns & 54.30 & 31.96 \\
\hline
\end{tabular}

CP - cassava peel; PM - poultry manure; RH - rice husk; PW - pig waste; NA - no amendment 
Table 11b: Effects of the four soil organic amendments on the yield of maize and cowpea under intercrop

\begin{tabular}{|c|c|c|c|c|}
\hline $\begin{array}{l}\text { Treat- } \\
\text { ment }\end{array}$ & $\begin{array}{l}\text { Husked } \\
\text { cob wt } \\
\left(\mathrm{t} \mathrm{ha}^{-1}\right)\end{array}$ & $\begin{array}{c}\text { Dehusked } \\
\text { cob wt } \\
\left(\mathrm{t} \mathrm{ha}^{-1}\right)\end{array}$ & $\begin{array}{c}\text { Fresh } \\
\text { pod weight } \\
\left(\mathrm{t} \mathrm{ha}^{-1}\right)\end{array}$ & $\begin{array}{c}\text { No. } \\
\text { of } \\
\text { cobs }\end{array}$ \\
\hline $\mathrm{CP}$ & $1.76 \times 10^{-4}$ & $1.24 \times 10^{-4}$ & $9.50 \times 10^{-6}$ & 1.83 \\
\hline PM & $3.58 \times 10^{-4}$ & $2.34 \times 10^{-4}$ & $1.54 \times 10^{-5}$ & 2.17 \\
\hline PW & $1.92 \times 10^{-4}$ & $1.36 \times 10^{-4}$ & $1.31 \times 10^{-5}$ & 1.83 \\
\hline RH & $1.64 \times 10^{-4}$ & $1.22 \times 10^{-4}$ & $1.00 \times 10^{-5}$ & 2.00 \\
\hline NA & $1.24 \times 10^{-4}$ & $9.00 \times 10^{-5}$ & $8.40 \times 10^{-6}$ & 1.73 \\
\hline $\mathrm{LSD}_{0.05}$ & $7.20 \times 10^{-5}$ & $4.50 \times 10^{-5}$ & $\mathrm{~ns}$ & $\mathrm{~ns}$ \\
\hline
\end{tabular}
PW - pig waste; NA - no amendment; wt - weight.

For maize-cowpea intercrop at 4 and 8 WAP (Table 11a), the growth parameters of maize plants both at 4 and 8 WAP revealed that plant height showed significant difference as the unamended (control) plot produced the lowest plant height compared to the amended plots.

There were no significant differences $(p>0.05)$ in the leaf area and number of leaves of the maize plant between the organic amendments used at $p<$ 0.05 . For cowpea at 4 and $8 \mathrm{WAP}$, the number of branches showed no significant differences. However, vine length differed significantly $(p<$ 0.05 ) between the organic amendments. PM had the highest vine length while plants on the unamended plots produced the lowest vine length. The yield of maize (Table 11b) at harvest followed the order $\mathrm{PM}>\mathrm{PW}>\mathrm{CP}>\mathrm{RH}>\mathrm{NA}$ while the yield of cowpea pod followed the order: $\mathrm{PM}>\mathrm{PW}$ $>\mathrm{RH}>\mathrm{CP}>\mathrm{NA}$. The results corroborate with the findings of Onunwa et al. (2019) that the yield improvements of maize and cowpea under both sole and intercropping systems were more marked in poultry manure-amended soil than in cassava peel-amended soil. This could be attributed to the richness of the poultry manure applied as compared to the other amendments (Table 2).

\section{CONCLUSION}

The study showed that the amendments improved soil physical and chemical properties such as $\mathrm{pH}$, organic carbon content; available phosphorous and exchangeable bases (K, $\mathrm{Ca}, \mathrm{Mg}$ and $\mathrm{Na}$ ). Generally, the increased soil organic matter resulted in increase in soil fertility. This increased organic matter as well improved soil physical and chemical properties. Maize and cowpea responded to organic amendments in terms of growth and yield which were reflected in the plant height, vine length, number of leaves, number of branches, number of cobs, weight of husked and dehusked cobs and weight of cowpea pods. Based on the findings, poultry manure performed better than pig waste, rice husk and cassava peels in improving the soil physicochemical properties as well as enhancing the growth and yield of maize and cowpea both as sole and intercrop within the study area.

\section{REFERENCES}

Adubasim C.V., Igwenagu C.M., Josiah G.O. et al. (2018). Substitution of manure source and aerator in nursery media on sandy-loam topsoil and their fertility indices 4 months after formulation. Int. J. Recycling Organic Waste Agric., 7 (4), 305-312. DOI: $10.1007 / \mathrm{s} 40093-018-0216-8$

Andrew C.S. and Jones R.K. (1978). The phosphorus nutrition of tropical legumes. In: Mineral Nutrition of Legumes in Tropical and Subtropical Soils (pp. 295-311). Commonwealth Scientific and Industrial Research Organisation (CSIRO). US/Australia Cooperative Science Program 1978, pp. 295-311

Anikwe M.A.N. (2000). Amelioration of a heavy clay loam with rice husk dust and its effects on soil physical properties and maize yield. Bioresource Technol., 74 (2), 169-173. https://doi.org/10.1016/ S0960-8524 (00)00007-9

Babalola T.S., Afolabi S.K., Kadiri W.O.J., Ayodele O.J. and Aruleba J.A. (2015). Soil and crop management practices among farmers in Kabba/Bunu Local Government Area, Kogi State. Agro-Science, 14 (2), 30-35. https://doi.org/10.4314/as.v14i2.5

Baiyeri P.K., Ugese F.D., Obalum S.E. and Nwobodo C.E. (2020). Agricultural waste management for horticulture revolution in sub-Saharan Africa. CAB Reviews 2020 15, No. 017. DOI: 10.1079/PAVSNNR202015017

Blake G.R. and Hartge K.H. (1986) Bulk density. In: Klute A. (ed.), Methods of Soil Analysis, Part 1 Physical and Mineralogical Methods, $2^{\text {nd }}$ ed., Agronomy Monograph 9, American Society of Agronomy - Soil Science Society of America, Madison WI, pp. 363-382

Bot A. and Benites J. (2005). The importance of soil organic matter: Key to drought-resistant soil and sustained food production. Food and Agriculture Organization (FAO) of the United Nations, p.78

Bray R.H. and Kurtz L.T. (1945). Determination of total organic and available forms of phosphorous in soil. Soil Sci., 599, 39-49

Cereda M.P. and Mattos M.C.Y. (1996). Linamarin: The toxic compound of cassava. J. Venom. Anim. Toxins, 2 (1), 6-12. https://doi.org/10.1590/S0104-79301996 000100002

Chan K.Y., Heenan D.P. and So H.B. (2003). Sequestration of carbon and changes in soil quality under conservation tillage on light-textured soils in Australia: A review. Austr. J. Exp. Agric., 43 (4), 325-334. https://doi.org/10.1071/EA02077

Crews T.E. and Peoples M.B. (2004). Legume versus fertilizer sources of nitrogen: Ecological tradeoffs and human needs. Agric. Ecosys. Environ., 102 (3), 279-297. https://doi.org/10.1016/j.agee.2003.09.018

Demir Z. and Gulser C. (2015). Effects of rice husk compost application on soil quality parameters in greenhouse conditions. Euras. J. Soil Sci., 43, 185-190. https://doi.org/10.18393/ejss.2015.3.185-190

Desse G. and Taye M. (2001). Microbial load and microflora of cassava (Manihot esculenta Crantz) and effect of cassava juice on some food borne pathogens. J. Food Technol. Afr., 6 (1), 21-24. https://doi.org/10.4314/jfta.v6i1.19279

Ebaid R.A. and El-Refaee I.S. (2007). Utilization of rice husk as an organic fertilizer to improve productivity and water use efficiency in rice fields. $8^{\text {th }}$ African Crop Science Society Conference, El-Minia, Egypt, 27-31 October, pp. 1923-1928 
Eneje R.C. and Uzoukwu I. (2012). Effect of rice mill waste properties and growth and yield of maize. Nig. J. Soil Sci., 22, 59-64

Ewulo B.S., Ojeniyi S.O. and Akanni D. A. (2008). Effect of poultry manure on selected soil physical and chemical properties, growth, yield and nutrient status of tomato. Afr. J. Agric. Res., 3 (9), 9-14

Ezenwaji E.E., Phil-Eze P.O., Enete I.C. and Osuiwu B.O. (2014). An analysis of the cycles and periodicities of annual rainfall over Awka Region, Nigeria. Atm. Clim. Sci. 4

665-671. https://doi.org/10.4236/acs.2014.44059

Gallardo-Laraa F. and Nogales R. (1987). Effect of the application of town refuse compost on the soil-plant system: A review. Biol. Wastes, 19 (1), 35-62

Gee G.W. and Bauder J.W. (1986). Particle size analysis. In: A. Klute (ed.), Methods of Soil Analysis. Part 1 (pp. 91-100). American Society of Agronomy, Madison WI, USA

Genstat. (2006). Genstat for windows ( $9^{\text {th }}$ edition). Lawes Agricultural Trust, Rothamsted Experimental Station

Gruhn P., Goletti F. and Yudelman M. (2000). Integrated Nutrient Management, Soil Fertility, and Sustainable Agriculture: Current Issues and Future Challenges. Food, Agriculture, and the Environment Discussion Paper 32. Washington DC: International Food Policy Research Institute (IFPRI)

Jalota S.K., Khera R. and Ghuman B.S. (1998). Method in Soil Physics. Narosa Publ. House, New Delhi pp. 65-67

Kolavalli S. and Adam S. (2011). Manure Use in Northern Ghana: Observations from a Fieldtrip. http://gssp.ifpri. info/files/2011/06/manure-use-in-northern ghana3.docx

Lithourgidis A., Vasilakoglou I., Dhima K.V., Dordas C. and Yiakoulaki M.D. (2006). Forage yield and quality of common vetch mixtures with oat and triticale in two seeding ratios. Field Crop. Res., 9 (2-3), 106-113. https://doi.org/10.1016/j.fcr.2006.03.008

Logah V. (2009). Soil fertility and Microbial Biomass Carbon, Nitrogen and Phosphorus Dynamics under Different Amendments and Cropping Systems in Ghana (PhD Thesis). Kwame Nkrumah University of Science and Technology (KNUST), Kumasi, Ghana

Madhumita S., Bhattacharyya S. and Behera R.C. (2009). Effect of temperature on morphology and phase transformations of nano crystalline silica obtained from rice husk. Phase Transit., 82 (5), 377-386

Mbagwu J.S.C. (1992). Improving the productivity of a degraded ultisol in Nigeria using organic and inorganic amendments. Part 2: Changes in physical properties. Bioresource Technol., 42 (3), 167-175

McLean E. (1982). Soil pH and lime requirement. In: Page A.L., Miller R.H. and Keeney D.R. (eds.), Methods of Soil Analysis. Part 2 (pp. 199-224). American Society of Agronomy, Soil Science Society of America, Madison WI, USA

Mengel K. and Kirkby E.A. (2001). Principles of Plant Nutrition. Kluwer Academic Publishers. https://doi. org/10.1007/978-94-010-1009-215

Nabhan H. (1997). Land degradation in relation to food security with focus on soil fertility management. Proc. Expert Consultation on Integrated Soil Manage. for Sustainable Agric. \& Food Security in Southern \& East Africa held in Harare, Zimbabwe on 8-12 Dec., 49-90

Nelson D.W. and Sommers L.W. (1982). Chemical and Microbiological properties. In: Page A.L., Miller R.H. and Keeney D.R. (eds.), Methods of Soil Analysis, 2 (pp. 301-312), American Society of Agronomy 9, Madison WI, USA
Nnabude P.C. and Mbagwu J.S.C. (1999). Soil water relations of a Nigerian typic haplustult amended with fresh and burnt rice-mill wastes. Soil Tillage Res., 50, 207-208. https://doi.org/10.1016/S0167-1987(98)00193-7

Nnoke F.N. (2005). Concise Soil Handbook. Innarrok. Abakaliki, Ebonyi State (Nigeria): Innarrok

Obalum S.E., Chibuike G.U., Peth S. and Ouyang Y. (2017). Soil organic matter as sole indicator of soil degradation. Environ. Monitoring Assessment, 189 (4), Article 176. DOI: 10.1007/s10661-017-5881-y

Obalum S.E., Okpara I.M., Obi M.E. and Wakatsuki T. (2011). Short-term effects of tillage-mulch practices under sorghum and soybean on organic carbon and eutrophic status of a degraded Ultisol in southeastern Nigeria. Trop. Subtrop. Agroecosys., 14 (2), 393-403

Okonkwo C.I., Mbagwu J.S.C., Egwu S.O. and Mbah C.N. (2011). Effect of decomposed rice husk dust on soil properties and yield of maize. J. Agric. Biol. Sci., 2 (5), 129-135

Onunwa A.O., Igwe C.A., Ezema R.A. and Uko I. (2019). Tillage and residual effect of some organic amendments on selected soil chemical properties and yield of maize and cowpea intercrop in a tropical ultisol. Int. J. Appl. Sci. Eng., 7 (1), 1-8

Petersen S.O., Sommer S.G., Béline F., et al. (2007). Recycling of livestock manure in a whole-farm perspective. Livestock Sci., 112 (3), 180-191. https://doi.org/doi.org/10.1016/j.livsci.2007.09.001

Ramesh P., Singh M. and Rao A.S. (2005). Organic farming: Its relevance to the Indian context. Current Sci., 88 (4), 561-568. https://doi.org/10.2307/24110255

Richards L.A. (1954). Diagnosis and Improvement of Saline and Alkaline Soils: Agricultural handbook (p. 60). United States Department of Agriculture (USDA)

Sanchez P.A., Buresh R.J. and Leakey R.R. (1997). Trees, soils and food security. Philosophical Transaction of the Royal Society of London (Biological Sciences), 352, 949-961. https://doi.org/doi.org/10.1098/rstb.1997.0074

Sanchez P.A. and Leakey R.R.B. (1997). Land use transformation in Africa: Three determinants for balancing food security with natural resources utilization. Euro. J. Agron., 7 (1), 15-23. doi.org/10.1016/S0378-519X(97)80004-9

Savci S. (2012). An agricultural pollutant: chemical fertilizer. Int. J. Environ. Sci. Dev., 3 (1), 77-80. https://doi.org/10.7763/IJESD.2012.V3.191

Sommer S.G., Christensen M.L., Schmidt T. and Jensen L.S. (2013). Animal Manure Recycling: Treatment and Management. John Wiley and Sons Ltd. https://doi.org/10.1002/9781118676677

Tsubo M., Fukai S., Basnayake J., Tuong T.P., Bouman B. and Harmpichitvitaya D. (2005). Estimating percolation and lateral water flow on sloping land in rainfed lowland rice ecosystem. Plant Prod. Sci., 8 (3), 354-357. https://doi.org/10.1626/pps.8.354

Ugwu V.U., Nnadi A.L., Adubasim C.V. et al. (2020). Organic-waste aerator could completely displace poultry-droppings manure in nursery media based on coarse-textured soil: evidence with cashew seedlings. In: Baiyeri K.P. and Aba S.C. (eds.), Sustainable Horticulture Production System Intensified (pp. 941-951), Proc. 38th Annual Conf. Hort. Soc. Nigeria (HORTSON), University of Nigeria Nsukka, 25-31 Oct. 2020

Warman P. (1981). The basics of green manuring. MacDonald Journals, 40, 3-6 